\title{
The Relationship between Elementary School Students' Reading Comprehension and Reading Motivation
}

\author{
Yasemin Kuşdemir ${ }^{1}$, Pınar Bulut ${ }^{2}$ \\ ${ }^{1}$ Department of Primary Education, Kırıkkale University, Kırıkkale, Turkey \\ ${ }^{2}$ Department of Primary Education, Gazi University, Ankara, Turkey \\ Correspondence: Pınar Bulut, Faculty of Gazi Education, Department of Primary Education, Gazi University, Ankara, \\ Turkey.
}

Received: September 3, 2018

doi:10.11114/jets.v6i12.3595
Accepted: October 11, $2018 \quad$ Online Published: October 17, 2018

URL: https://doi.org/10.11114/jets.v6i12.3595

\begin{abstract}
Reading is an important language skill whose main purpose is comprehension. In the reading process, visible symbols must be perceived and interpreted in the brain. Once the reading skill has been acquired, it can become a tool for having access to information, analyzing and interpreting it. All of these depend on the reading comprehension skill. Thus, evaluation of reading comprehension is one of the subjects to which great importance is attached. Particularly the evaluation of the level of students' reading comprehension is a subject of great interest for many researchers. In this regard, the current study aimed to investigate the relationship between the Turkish elementary school students' reading comprehension and reading motivation. At the end of the study, it was found that there is a positive, medium and significant correlation between the students' levels of reading comprehension determined with cloze tests made up of both narrative and informative texts and reading motivation. In addition, a positive, medium and significant correlation was found between the students' levels of reading comprehension determined with open-ended questions made up of both narrative and informative texts and reading motivation. Increase in the students' reading motivation affects their reading comprehension positively and significantly. Furthermore, reading motivation explains $12-13 \%$ of the total variance in their reading comprehension.
\end{abstract}

Keywords: reading comprehension, reading motivation, open-ended question, cloze test

\section{Introduction}

Reading is a process which starts with seeing, continues with the reception of information on the basis of attention and perception and results in comprehension in the brain. Reading is therefore a complex language skill that requires many skills to be used at the same time. When the definitions of reading are examined, it is understood that very different aspects of reading are emphasized. While Harris and Sipay (1990) put the greatest emphasis on interpretation in reading, Schunk (2014) states that the process of perception in reading refers to vocabulary recognition and argues that conception means assigning meaning to printed information, which relies on the process of disintegration into elements. Reading skill entails processing information for word recognition, finding the main idea, understanding the details, recognizing the structure of the text and predicting the idea of the author, grasping the importance of the ideas in the text and evaluating and remembering all of these. These sets of knowledge and experience are well-known schemes and they can help readers to read. Such readers first understand the meaning of the content and then associate new knowledge with previously learned materials (Susanti, Buan \& Suhartono, 2013). For reading comprehension to occur, cognitive skills must have already been acquired. It is also important to determine the extent to which reading skill has been acquired as a skill activating higher order skills. In the process of evaluating reading comprehension, there are basic questions that teachers and field researchers must answer (Çiftçi and Temizyürek, 2008, p.111):

- What should be known about students in order to conduct this evaluation? (Knowing the student)

- Is theoretical knowledge sufficient for evaluation? (Questions - scoring)

- What is the purpose of determination and evaluation of reading comprehension level?

- Is one-type of question adequate to evaluate reading comprehension?

- How much will the student's having/not having information about text types and structures affect the result? 
- How much guidance can be provided by the objectives set for reading comprehension in the evaluation of reading comprehension?

In the determination of the level of reading comprehension, prior knowledge about the subject addressed in the text, text structure and knowledge of syntax and the extent to which cognitive strategies are capitalized on play roles. Knowing which strategies the student uses in this process also can offer some insights about the student's ability to learn new reading strategies (Schirmer, 2010, p.52). It is not right to think that reading is a skill that depends only on cognitive factors. Reading is also influenced by emotional / affective factors such as self-efficacy, self-confidence, attitude, and motivation. Since the relationship between reading comprehension and reading motivation has been investigated in this research, motivation has also been addressed in this section. "Motivation is a concept that helps us to understand why people act in certain ways" (Schunk, 2014, p.453). Motivation is the drive and desire that activate the organism for a purpose, give energy needed to maintain this activity and determine the direction of the activity (Slavin, 2013). In fact, motivation is a complex term. Not each child is motivated in a similar way. For real learning to occur, students should have positive attitudes towards themselves as learners, their abilities needed to be successful at school and the objectives set by themselves, their teachers and school (Graves, Juel, Graves \& Dewitz, 2011: 50). The theory of motivation has two main components: Intrinsic motivation and extrinsic motivation. Intrinsic motivation refers to the students' engaging in something which he/she finds interesting and enjoyable in itself (Ryan \& Deci, 2000); extrinsic motivation is associated with the desire to gain rewards and incentives that can be manipulated (Wang \& Guthrie, 2004). The sources of intrinsic motivation include positive experiences regarding reading, getting pleasure from reading, personal importance of reading. Extrinsic reading motivation on the other hand may vary depending on the effects of the tools presented by family and peers in an age-dependent manner (Becker, McElvany, \& Kortenbruck 2010, p.774). In a study conducted on the elementary school first and third grade students, the students' reading motivation and reading comprehension were evaluated at one year interval. The obtained results confirmed the reciprocal relationship between the participation (one component of intrinsic motivation) and reading comprehension at word and sentence levels. Furthermore, it was found that competition-oriented reading motivation (one component of extrinsic motivation) predicts reading comprehension while adversely affecting reading comprehension. The results show that even at the initial stages of learning process, the intrinsic reading motivation contributes to the development of the students' reading competence (Schiefele, Franziska, Schaffner, 2016). The factors affecting the student's motivation can be addressed within two groups (Tompkins, 2006, p.236):

\section{Teacher-Based Situations}

\subsection{Attitude:}

$\checkmark \quad$ The teacher should show students that he/she cares about them.

$\checkmark \quad$ The teacher should be enthusiastic about the subjects he/she teaches.

$\checkmark \quad$ The teacher should arouse students' curiosity for learning

1.2. Delivery of the lesson:

$\checkmark \quad$ The teacher should focus on his/her students' long-term learning.

$\checkmark \quad$ The teacher should enable students to be engaged in authentic activities.

$\checkmark \quad$ The teacher should teach his/her students how to be a strategic reader-writer

\section{Student-based situations:}

\subsection{Expectations:}

$\checkmark \quad$ Students should be expected to be successful.

$\checkmark \quad$ Students should be taught to set realistic objectives.

\subsection{Cooperation:}

$\checkmark \quad$ Students should work in cooperation.

$\checkmark$ Competition should be minimized.

$\checkmark \quad$ Students should be allowed to make plans and to offer alternatives.

\subsection{Competence in Reading and Writing:}

$\checkmark \quad$ Students should be taught how to use reading and writing strategies.

$\checkmark \quad$ Students should be provided with opportunities to read and write on a daily basis.

$\checkmark \quad$ The reciprocal writing technique should be used to help children experiencing problems in writing. 


\section{$\checkmark$ The required guidance should be offered to children having difficulty.}

The evaluation process of reading comprehension skills involves "making decisions regarding the teacher, student, instruction and curriculum and supplementary and complementary activities" (Üstüner and Şengül, 2004, p.201). In the evaluation process of reading whose main goal is to comprehend the text, different tools and methods can be used. These can be tests consisted of different types of questions such as open-ended and close or methods such as summarizing and retelling what you have read. Reading is a language skill that is affected from many variables. Prior knowledge, motivation, attention, self-efficacy, text structure and the student's interest in the topic of the text are among them. However, it is usually not possible to evaluate comprehension by taking all these variables into consideration. The current study employed two tools to reveal a clearer picture of the evaluation of the students' reading comprehension. As the elementary school students' reading comprehension was measured with the tests comprised of close questions and open-ended questions, information about only these tests is given.

Close Test: Close test used to evaluate reading comprehension can reveal important insights about the skills and strategies used to guess meaning from the text (Karasu, Girgin \& Uzuner, 2013b, p.702). Close tests are widely used to determine the level of reading comprehension. While the student is trying to fill in the blanks given within the text by writing the correct/appropriate words, he/she must read and understand. In this process, what is expected of the student is to find the appropriate word for the blank within the context of the text. This requires the student to focus on the text and use his/her prior knowledge. The words used by the student to fill the blanks can be wrong or mad-up. The student needs to be encouraged to find the correct word. The benefits of close tests to students can be summarized as follows (Putra, 2010, p.41):

- They can be used as diagnostic tests to determine the appropriateness of a text for the level of students and its level of difficulty.

- They can be used in the process of diagnosing students' existing level of comprehension.

- They can help students establish links between words and meanings.

The preparation process of a close test consists of simple steps. A close test can be prepared by first finding a text suitable for the age, developmental characteristics and reading-writing level of students and then deleting each fifth, seventh or ninth word in the text after the first sentence. In a 100-word text, if each fifth word is deleted then we will have nearly 20 blanks in total. While the reader is reading, he/she writes the words he/she thinks related to the text in these blanks. Then the reading comprehension score of the student is calculated by multiplying the point pre-determined for each blank with the number of correct words.

Open-ended Questions: One of the tools that can be used to measure reading comprehension is tests made up of open-ended questions. These tests are constituted by questions asked to students in relation to the text and students are expected to answer these questions with their own words. While answering open-ended questions, students are allowed to generate their own responses, to provide different responses unique to each student and to answer the questions from their own perspectives (Alkan, 2013, p.4). One of the important factors to be considered in the preparation process of open-ended questions is their appropriateness for the level of the target population and their level of difficulty. Open-ended questions can be at different levels of difficulty ranging from the level of knowledge to the level of application. This will naturally affect the scoring of the questions. Çıkrıkçı Demirtaşlı (2010) point out that the time required to answer an open-ended question should be determined on the basis of the content of the anticipated answer and its level of difficulty and the point to be assigned to such a question can vary depending on the complexity and abstractness of the thinking process required by the answer.

\subsection{Purpose of the Study}

The main purpose of the current study is to investigate the relationship between different question types used to determine the elementary school fourth grade students' level of reading comprehension and their reading motivation. To this end, two different types of text were selected and two tests for each text (open-ended questions and close test) were used. Given that reading motivation is an important variable affecting reading comprehension, the students' reading motivation was also evaluated through a scale and the correlation between the variables was tested. Within the context of the study, answers to the following questions were sought:

1. Do the elementary school fourth grade students' level of reading comprehension determined with the close tests vary significantly depending on;

1.1. Their gender,

1.2. The gender of their classroom teacher,

1.3. Whether they have taken pre-school education? 
2. Do the elementary school students' level of reading comprehension determined with the open-ended questions vary significantly depending on;

\subsection{Their gender,}

2.2. The gender of their classroom teacher;

2.3. Whether they have taken pre-school education?

3. Do the elementary school fourth grade students' reading motivation vary significantly depending on;

\subsection{Their gender,}

3.2. The gender of their classroom teacher;

3.3. Whether they have taken pre-school education?

4. Is there a significant correlation between the elementary school fourth grade students' level of reading comprehension determined with the close tests and their reading motivation?

5. Is there a significant correlation between the elementary school fourth grade students' level of reading comprehension determined with the open-ended questions and their reading motivation?

\section{Method}

\subsection{Research Model}

The current study was designed in the survey model. The main goal in this model is to determine the existing state of the selected issue and to describe the existing state without exercising any influence. As the purpose of the current study was to investigate the relationship between the Turkish elementary school students' level of reading comprehension and reading motivation, it was designed in line with the relational survey model.

\subsection{Universe and Sampling}

The universe of the current study is comprised of the elementary school fourth grade students attending the elementary schools located in the Yerköy province of the city of Yozgat in Turkey. In order to determine the sampling to represent the universe, first the number of the elementary schools and the number of the fourth grade students in these schools were determined. It was found that there were 8 elementary schools and a total of 421 fourth grade students attending these schools in the Yerköy province in 2017 - 2018 school year. In the selection of the sampling, the convenience sampling method was used. The convenience sampling method was preferred in the current study considering the factors such as cost, time and availability. According to Cohen, Manion and Morrison (2007) when the size of the universe is 400 or more, the size of the sampling should be 162 with $90 \%$ confidence; thus, the size of the sampling in the current study was determined to be 165 . Though the data were collected from 165 elementary school fourth grade students, inadequately responded forms were excluded from evaluation. Thus, analyses were conducted on the responses of a total of 119 students. Personal information about the students making up the sampling is given in Table 1.

Table 1. Demographic information about the students making up the sampling

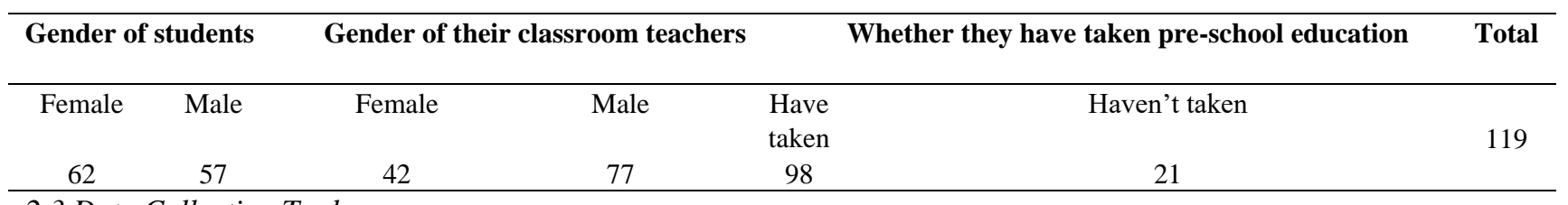

2.3 Data Collection Tool

The data collection tool used in the study is made up of three parts. In the first part, there are three questions aiming to elicit some demographic information of the students. In the second part, there is the 22-item "Text-oriented Reading Motivation Scale" developed by Aydemir and Öztürk (2013). In the third part of the data collection tool, there are two texts and two tests for each text taken from the Informal Reading Inventory developed by Karasu, Girgin and Uzuner (2013a). One of these texts is a narrative text called "Arda is on Holiday" and the other one is an informative text called "Eating". Detailed information about each part of the data collection tool is given below:

Personal Information Part: In order to elicit some demographic information about the participants, a part consisted of three items was formed. These three items are given below:

Gender: Female( ) Male( )

Gender of the Classroom Teacher: Female ( ) Male ( )

You have taken pre-school education: I have( ) I haven't ( ) 
Text-oriented Reading Motivation Scale: This scale was developed by Aydemir and Öztürk (2013). The scale is comprised of four factors which are named as "perception of reading difficulty", "reading efficacy", "reading-related effort/appreciation" and "social dimension of reading" and 22 items. The four factors in the scale explain $46.23 \%$ of the total variance. The internal consistency coefficient of the scale (alpha) was found to be .81 . The scoring of the five-point Likert-type scale is as follows: "It is very suitable for me" 5 points; "It is suitable for me" 4 points; "Undecided" 3 points; "It is not suitable for me" 2 points; "It is not suitable for me at all" 1 point. For the negatively worded items, the scoring is reversed and thus total scores are calculated. In the current study, before the administration of the scale, a reliability analysis was conducted and Cronbach alpha coefficient was found to be 0.78 .

Close Test: This is a close test found in the Informal Reading Inventory developed by Karasu, Girgin and Uzuner (2013a). In the current study, two different tests one of which was prepared for a narrative text "Arda is on Holiday" and the other one for an informative text "Eating" were used. The tests were prepared according to the principles of close test development and they were created by deleting the each fifth word after the first sentence. The first and last sentences of the texts were left untouched. If the fifth word to be deleted within the text was a proper noun then the sixth word was deleted. Within the response time, the student starts to read the text from the first sentence and then writes the word he/she considers to be suitable for the blank and then continues to read. In the scoring of the close test, the suitability of the written word to the sentence structure, meaning and letter-sound harmony was also taken into consideration. The scoring was performed at three different levels: first level "filling in the blank with a word same as the one in the text"; second level "filling in the blank with a word different from the one in the text but not changing the meaning" and third level "filling in the blank with a word changing the meaning" and the blanks left uncompleted were considered to be at the third level. The number of words at each level was divided by the number of blanks and then multiplied with 100 to calculate the rate of success (Girgin, 2006; Thackwell, 1992; Aktaran Karasu, Girgin \& Uzuner, 2013a, p.32). The evaluation of the students' levels of reading comprehension with the close test developed from the narrative text (Karasu, Girgin \& Uzuner, 2013a, p.42) is given in Table 2:

Table 2. Reading comprehension levels determined with the close tests

\begin{tabular}{ll}
\hline Comprehension level & Point \\
\hline Independent level & $60 \%$ and higher \\
Instructional level & $40-60 \%$ \\
Challenging level & $40 \%$ and lower
\end{tabular}

Open-Ended Questions: The data collection tool structured on two different texts and made up of open-ended questions was derived from the Informal Reading Inventory developed and published by Karasu, Girgin and Uzuner (2013a). The two texts in this inventory were used in the current study. One of these is an informative text entitled as "Eating" and it consists of 175 words. There are 8 open-ended questions to be answered from this text and each question is worth 12.5 points. The other text taken from the Informal Reading Inventory consists of 242 words and is entitled as "Arda is on Holiday". There are a total of 10 questions for the text "Arda is on Holiday" and each question is worth 10 points. The total score to be taken for both of these texts is 100 . The questions to be answered on the basis of the two texts were classified as textually open, textually closed and knowledge-experience questions. For each type of question, a sample question is given below:

Textually open question: [What is the use of protein?]

Textually closed question: [What do we need to do not to gain weight?]

Knowledge-experience question: [If there weren't the fisherman, what would Arda do?]

The criteria for the evaluation of the total score to be taken from these questions are given below (Karasu, Girgin $\&$ Uzuner, 2013, p.42):

90 and higher points: Independent Level

75-89 points: Absolute Instructional Level

51-74 points: Transitional Instructional Level

50 and lower points: Level of Difficulty

\subsection{Data Collection and Analysis}

The data of the current study were collected in the Yerköy province of the city of Yozgat in Turkey in February 2018. First, required permissions were taken from school administrations and then the application was conducted in the 
classes of the classroom teachers who volunteered to participate in the study. The data were collected at different times and at five stages. Information about these stages is given in Table 3.

Table 3. The procedure followed in the application process

\begin{tabular}{llc}
\hline Application & Data & Application time \\
\hline Personal Information Form & 02.01 .2018 & 10 minutes \\
Text-oriented Reading Motivation Scale & 02.01 .2018 & 15 minutes \\
Close Test 1 (Arda is on Holiday) & 05.01 .2018 & 40 minutes \\
Close Test 2 (Eating) & 09.01 .2018 & 40 minutes \\
Open-ended Question Test 1 (Arda is on Holiday) & 12.01 .2018 & 40 minutes \\
Open-ended Question Test 2 (Eating) & 17.01 .2018 & 40 Minutes \\
\hline
\end{tabular}

In the analysis of the data, first the data collection tools not completed as required or too inadequately completed to be evaluated were excluded from analysis. The data obtained from the Personal Information Form and Text-oriented Reading Motivation Scale" were entered to a statistics program in the computer environment. The answers given to the close tests were checked and counted by two researchers and the test of each student was scored individually. In the current study, the students' responses were scored separately by the two researchers. Therefore, inter-rater agreement was calculated and $97 \%$ agreement was found between the researchers. The total scores taken by each student from the close tests and open-ended question tests were recorded in the statistics program in the computer environment. Prior to the analysis of the collected data, in order to determine which analyses would be used, the normality test was conducted.

Table 4. Test of Normality

\begin{tabular}{llll}
\hline & \multicolumn{3}{c}{ Shapiro -Wilk } \\
\hline & Statistic & df & Sig. \\
\hline Student gender &, 636 & 119 &, 146 \\
Teacher gender &, 604 & 119 &, 138 \\
Pre-school education &, 462 & 119 &, 111 \\
\hline
\end{tabular}

$\mathrm{p}>.05$

As the data were found to exhibit a normal distribution the independent-samples t-test was run on the personal information data. In order to analyze the relationship between reading comprehension and reading motivation, the bilateral correlation analysis was conducted and in order to reveal the extent to which reading motivation predicts reading comprehension, the simple linear regression analysis was used.

\section{Findings}

In this section, the findings obtained from the analyses of the collected data are presented in line with the main and sub-goals of the current study.

\subsection{Investigation of the Elementary School Students' Levels of Reading Comprehension in Relation to Different Question Types}

The independent-samples t-test was performed to determine whether the elementary school fourth grade students' level of reading comprehension varies significantly depending on their gender, the gender of their classroom teacher and whether they have taken pre-school education. The findings obtained from the gender-based comparison of the participating students' reading comprehension scores taken from the close tests are presented in Table 4.

Table 5. The gender-based distribution of the reading comprehension scores determined with the close tests

\begin{tabular}{lccccccc}
\hline Close test & Gender & n & $\overline{\mathbf{x}}$ & ss & sd & t & p \\
\hline Informative Text & Female & 62 & 58.82 & 19.33 & & \multirow{2}{*}{4.203} & .000 \\
(Eating) & Male & 57 & 44.51 & 17.66 & \multirow{2}{*}{117} & & \\
Narrative Text (Arda is on & Female & 62 & 71.84 & 19.12 & & 5.400 & .000 \\
Holiday) & Male & 57 & 52.14 & 20.67 & & & .000 \\
\hline
\end{tabular}

$\mathrm{p}<.05$

As can be seen in Table 4, the arithmetic mean of the female students' reading comprehension scores taken from the close test prepared from the informative text $(\overline{\mathrm{x}}=58.82)$ is higher than that of the male students' reading comprehension scores taken from the same close test $(\overline{\mathrm{x}}=44.51)$. The arithmetic mean of the female students' reading comprehension scores taken from the close test prepared from the narrative text $(\bar{x}=71.84)$ is higher than that of the male students' reading comprehension scores taken from the same test $(\bar{x}=52.14)$. These mean scores show that both female and male students are more successful in narrative texts when compared to informative texts. In the results of the analyses, $p$ value was found to be smaller than .05 , showing that the students' level of reading comprehension varied significantly 
by gender in favor of the female students $[\mathrm{t}(117)=4.203$; $\mathrm{p}<.05 ; \mathrm{t}(117)=5.400]$. The other tests completed by the elementary school fourth grade students were the reading comprehension tests constituted by open-ended questions. In Table 5, the results of the analyses conducted on the students' responses to these tests are presented.

Table 6. The gender-based distribution of the reading comprehension scores determined with the open-ended question tests

\begin{tabular}{lccccccc}
\hline \multicolumn{1}{c}{ Open-ended Questions } & Gender & $\mathbf{n}$ & $\overline{\mathbf{x}}$ & ss & sd & $\mathbf{t}$ & $\mathbf{p}$ \\
\hline Informative text & Female & 62 & 65.04 & 22.65 & & \multirow{2}{*}{4.275} & .000 \\
(Eating) & Male & 57 & 48.48 & 19.30 & \multirow{2}{*}{117} & & \\
Narrative text & Female & 62 & 82.03 & 14.96 & & \multirow{2}{*}{3.014} & .003 \\
(Arda is on Holiday) & Male & 57 & 71.61 & 22.30 & & & \\
\hline
\end{tabular}

$\mathrm{p}<.05$

As can be seen in Table 5, the arithmetic mean of the female students' reading comprehension scores taken from the open-ended question test prepared from the informative text $(\overline{\mathrm{x}}=65.04)$ is higher than that of the male students' reading comprehension scores taken from the same test $(\overline{\mathrm{x}}=48.48)$. The arithmetic mean of the female students' reading comprehension scores taken from the open-ended question test prepared from the narrative text $(\bar{x}=82.03)$ is higher than that of the male students' reading comprehension scores taken from the same test $(\bar{x}=71.62)$. These mean scores show that both female and male students are more successful in narrative texts when compared to informative texts. In the results of the analyses, $\mathrm{p}$ value was found to be smaller than .05 , showing that the students' level of reading comprehension varied significantly by gender in favor of the female students $[t(117)=4.275 ; \mathrm{p}<.05 ; \mathrm{t}(117)=3.014]$. The current study also investigated whether the elementary school fourth grade students' level of reading comprehension varies significantly depending on whether they have taken pre-school education or not. The findings obtained in this regard are given in Table 6.

Table 7. The distribution of the comprehension scores determined with the close tests on the basis of their having taken pre-school education

\begin{tabular}{lccccccc}
\hline Close test & $\begin{array}{c}\text { Having pre-school } \\
\text { education or not }\end{array}$ & $\mathbf{N}$ & $\overline{\mathbf{x}}$ & ss & sd & t & $\mathbf{p}$ \\
\hline Informative text & I have & 98 & 53.73 & 20.18 & & 2.127 & .036 \\
(Eating) & I haven't & 21 & 43.74 & 15.96 & & & \\
Narrative text & I have & 98 & 63.13 & 22.29 & 117 & .766 & .445 \\
(Arda is on Holiday ) & I haven't & 21 & 59.04 & 21.51 & & & \\
\hline
\end{tabular}

$\mathrm{p}<.05$

As can be seen in Table 6, the arithmetic mean of the scores taken from the close test created with the informative text by the students having taken pre-school education $(\bar{x}=53.73)$ is higher than the arithmetic mean of the scores taken by the students not having taken pre-school education $(\overline{\mathrm{x}}=43.74)$. As the $\mathrm{p}$ value is lower than .05 , it can be argued that the reading comprehension scores taken from the close test created with the informative text vary significantly depending on taking or not taking pre-school education and this difference is in favor of students having taken pre-school education $[\mathrm{t}(117)=2.127 ; \mathrm{p}<.05 ; \mathrm{t}(117)=3.014]$. The arithmetic mean of the reading comprehension scores taken from the close test created with the narrative text by the students having taken pre-school education $(\overline{\mathrm{x}}=63.13)$ is higher than that of the reading comprehension scores taken by the students not having taken pre-school education $(\overline{\mathrm{x}}=59.04)$. However, as $\mathrm{p}$ value is higher than .05 , it can be said that there is no significant difference between the students' mean scores. The participating students' reading comprehension was also evaluated with the open-ended question tests. In Table 7, the distribution of the reading comprehension scores taken from the open-ended questions related to the informative and narrative texts on the basis of their having taken pre-school education is given.

Table 8. Distribution of the comprehension scores determined with the open-ended questions on the basis of having taken pre-school education

\begin{tabular}{|c|c|c|c|c|c|c|c|}
\hline Open-ended questions & $\begin{array}{l}\text { Having pre-school } \\
\text { education or not }\end{array}$ & $\mathbf{N}$ & $\overline{\mathbf{x}}$ & SS & Sd & $\mathbf{t}$ & $\mathbf{p}$ \\
\hline Informative text & I have & 98 & 59.03 & 23.27 & \multirow{3}{*}{117} & & \multirow{2}{*}{.045} \\
\hline (Eating) & I haven't & 21 & 48.14 & 16.89 & & 2.030 & \\
\hline $\begin{array}{l}\text { Narrative text } \\
\text { (Arda is on Holiday) }\end{array}$ & $\begin{array}{l}\text { I have } \\
\text { I haven't }\end{array}$ & $\begin{array}{l}98 \\
21\end{array}$ & $\begin{array}{l}78.59 \\
69.80\end{array}$ & $\begin{array}{l}18.68 \\
21.86\end{array}$ & & 1.896 & .060 \\
\hline
\end{tabular}

$\mathrm{p}<.05$

As can be seen in Table 7, the arithmetic mean of the scores taken from the open-ended questions developed for the informative text by the students having taken pre-school education $(\bar{x}=59.03)$ is higher than the arithmetic mean of the 
scores taken by the students not having taken pre-school education $(\bar{x}=48,14)$. As the $p$ value is lower than .05 , it can be argued that the reading comprehension scores taken from the open-ended questions developed for the informative text vary significantly depending on taking or not taking pre-school education and this difference is in favor of students having taken pre-school education $[\mathrm{t}(117)=2,030 ; \mathrm{p}<, 05]$. The arithmetic mean of the reading comprehension scores taken from the open-ended questions developed for the narrative text by the students having taken pre-school education $(\overline{\mathrm{x}}=78.59)$ is higher than that of the reading comprehension scores taken by the students not having taken pre-school education $(\overline{\mathrm{x}}=69.80)$. However, as $\mathrm{p}$ value is higher than .05 , it can be said that there is no significant difference between the students' mean scores. The students' reading comprehension scores were also evaluated on the basis of the gender of the students' classroom teacher. In this regard, the obtained findings are presented in Table 8.

Table 9. The distribution of the comprehension scores determined with the close tests according to the gender of the students' classroom teacher

\begin{tabular}{lccccccc}
\hline Close test & $\begin{array}{c}\text { Gender of the } \\
\text { classroom teacher }\end{array}$ & $\mathbf{n}$ & $\overline{\mathbf{x}}$ & Ss & sd & t & p \\
\hline Informative text & Female & 42 & 38.04 & 16.02 & & & \\
(Eating) & Male & 77 & 59.56 & 17.48 & 117 & 6.606 & .000 \\
Narrative text & Female & 42 & 51.30 & 16.88 & & & \\
(Arda is on Holiday) & Male & 77 & 68.46 & 22.38 & & 4.336 & .000 \\
\hline
\end{tabular}

$\mathrm{p}<.05$

As can be seen in Table 8 , the arithmetic mean of the reading comprehension scores taken by the students whose classroom teacher is female from the close test created with the informative text is $(\bar{x}=38.04)$ and the arithmetic mean of the scores taken by these students from the close test created with the narrative text is $(\overline{\mathrm{x}}=51.30)$. The arithmetic mean of the reading comprehension scores taken by the students whose classroom teacher is male from the close test created with the informative text is $(\bar{x}=59.56)$ and the arithmetic mean of the scores taken by these students from the close test created with the narrative text is $(\overline{\mathrm{x}}=68.46)$. As $\mathrm{p}$ value is lower than .05 , it can be said that the students' reading comprehension scores vary significantly depending on the gender of their classroom teacher and this difference is in favor of the students whose classroom teacher is male $[\mathrm{t}(117)=6.606 ; \mathrm{p}<.05 ; \mathrm{t}(117)=4,336]$. The students' reading comprehension scores determined with the open-ended questions were also evaluated depending on the gender of their classroom teacher. The findings obtained in this way are presented in Table 9.

Table 10. Distribution of the comprehension scores taken from the open-ended questions according to the gender of the students' classroom teacher

\begin{tabular}{lcccccccc}
\hline Open-ended questions & $\begin{array}{c}\text { Gender of } \\
\text { the } \\
\text { classroom } \\
\text { teacher }\end{array}$ & $\mathbf{N}$ & $\overline{\mathbf{x}}$ & Ss & sd & $\mathbf{t}$ & $\mathbf{p}$ \\
\hline Informative text (Eating) & $\begin{array}{c}\text { Female } \\
\text { Narrative text (Arda is on Holiday) }\end{array}$ & 42 & 42.38 & 20.57 & & 5.971 & .000 \\
\cline { 2 - 6 } & Male & 77 & 65.14 & 19.49 & 117 & & \\
& Female & 42 & 68.26 & 23.05 & & 3.838 & .000 \\
\hline
\end{tabular}

$\mathrm{p}<.05$

As can be seen in Table 9, the arithmetic mean of the comprehension scores taken by the students whose classroom teacher is female from the open-ended questions developed for the informative text $(\overline{\mathrm{x}}=42.38)$ is lower than the arithmetic mean of the comprehension scores taken by these students from the open-ended questions developed for the narrative text $(\overline{\mathrm{x}}=68.26)$. The arithmetic mean of the comprehension scores taken by the students whose classroom teacher is male from the open-ended questions developed for the informative text $(\bar{x}=65.14)$ is higher than the arithmetic mean of the comprehension scores taken by these students from the open-ended questions developed for the narrative text $(\bar{x}=51.30)$. As $\mathrm{p}$ value is lower than .05 , it can be said that the students' reading comprehension varies significantly depending on the gender of their classroom teacher. Yet, while this difference is in favor of the students whose classroom teacher is male for the open-ended questions developed for the informative text, it is in favor of the students whose classroom teacher is female for the open-ended questions developed for the narrative text $[\mathrm{t}(117)=5.971$; $\mathrm{p}<.05 ; \mathrm{t}(117)=3.838]$.

\subsection{Investigation of the Elementary School Fourth Grade Students' Reading Motivation}

The participating elementary school fourth grade students' reading motivation was explored depending on the variables of the student's gender, the gender of the students' classroom teacher and whether they have taken pre-school education 
or not. The findings obtained in this regard are discussed below. Table 10 presents the findings related to the elementary school fourth grade students' reading motivation in relation to the variable of gender.

Table 11. Investigation of reading motivation according to the student's gender

\begin{tabular}{lccccccc}
\hline \multirow{2}{*}{ Reading } & Student's gender & $\mathbf{n}$ & $\overline{\mathbf{x}}$ & ss & sd & $\mathbf{t}$ & $\mathbf{p}$ \\
\cline { 2 - 8 } motivation & Female & 62 & 4.44 & .32 & \multirow{2}{*}{117} & 4.655 & .000 \\
& Male & 57 & 4.10 & .46 & & & \\
\hline
\end{tabular}

$\mathrm{p}<.05$

As can be seen in Table 10, the arithmetic mean of the female students' reading motivation scores $(\overline{\mathrm{x}}=4.44)$ is higher than that of the male students' reading comprehension scores $(\bar{x}=4.10)$. As $p$ value is lower than .05 , the difference between the arithmetic means is statistically significant in favor of the female students [t(117) $=4.665 ; \mathrm{p}<.05]$. Thus, it can be maintained that the female students' reading motivation is higher than that of the male students. Table 11 presents the comparison of the reading motivation of the students on the basis of the gender of the students' classroom teacher.

Table 12. Investigation of the students' reading motivation according to the gender of the students' classroom teacher

\begin{tabular}{cccccccc} 
Reading motivation & $\begin{array}{c}\text { Gender of the } \\
\text { classroom teacher }\end{array}$ & $\mathbf{n}$ & $\overline{\mathbf{x}}$ & $\mathbf{s s}$ & sd & $\mathbf{t}$ & $\mathbf{p}$ \\
\cline { 2 - 9 } & $\begin{array}{c}\text { Female } \\
\text { Male }\end{array}$ & 42 & 4.09 & .50 & 117 & 3.635 & .000 \\
\hline
\end{tabular}

$\mathrm{p}<.05$

The students' reading comprehension was compared according to the gender of their classroom teacher. The arithmetic mean of the students whose classroom teacher is female is $(\overline{\mathrm{x}}=4.09)$ and the arithmetic mean of the students whose classroom teacher is male is $(\bar{x}=4.37)$. As p value is lower than .05 , it can be said that the difference between the means is statistically significant favoring the students whose classroom teacher is male $[t(117)=3.635 ; \mathrm{p}<.05]$. Thus, it can be argued that reading motivation of the students whose classroom teacher is male is higher than that of the students whose classroom teacher is female. The participating students' reading motivation was also investigated in relation to their having taken pre-school education or not. The findings obtained in this regard are presented in Table 12.

Table 13. Investigation of reading motivation according to the students' having taken pre-school education or not

\begin{tabular}{|c|c|c|c|c|c|c|c|}
\hline \multirow{3}{*}{$\begin{array}{c}\text { Reading } \\
\text { motivation }\end{array}$} & Having pre-school education & $\mathbf{n}$ & $\overline{\mathbf{x}}$ & SS & sd & $\mathbf{t}$ & $\mathbf{p}$ \\
\hline & I have & 98 & 4.32 & .43 & \multirow{2}{*}{117} & \multirow{2}{*}{2.366} & \multirow{2}{*}{.020} \\
\hline & I haven't & 21 & 4.08 & .37 & & & \\
\hline
\end{tabular}

$\mathrm{p}<.05$

As can be seen in Table 12, reading motivation of the students having taken pre-school education $(\bar{x}=4.32)$ is higher than that of the students not having taken pre-school education $(\overline{\mathrm{x}}=4.08)$. As $\mathrm{p}$ value is lower than .05 , the difference between the means is statistically significant in favor of the students having taken the pre-school education $[\mathrm{t}(117)=$ $2.366 ; \mathrm{p}<.05]$.

\subsection{Investigation of the Relationship between the Elementary School Fourth Grade Students' Reading Comprehension} Levels and Reading Motivation

The findings obtained through the correlation analysis conducted to determine the correlation between the students' reading comprehension scores determined with the close tests and reading motivation are presented in Table 13.

Table 14. Comparison of the level of comprehension determined through the close tests with their reading motivation

\begin{tabular}{lccc}
\hline \multicolumn{1}{c}{ Close test } & $\begin{array}{c}\text { Informative text } \\
\text { (Eating) }\end{array}$ & $\begin{array}{c}\text { Narrative text } \\
\text { (Arda is on Holiday) }\end{array}$ & $\begin{array}{c}\text { Reading } \\
\text { motivation }\end{array}$ \\
\hline $\begin{array}{l}\text { Informative text } \\
\text { (Eating) }\end{array}$ & 1 & & \\
$\begin{array}{l}\text { Narrative text } \\
\text { (Arda is on Holiday) }\end{array}$ & $.711^{* *}$ & 1 & \\
Reading motivation & $.371^{* *}$ & $.364^{* *}$ & 1 \\
\hline
\end{tabular}

$* * \mathrm{p}<.01$ 
As can be seen in Table 13, there is a positive, medium and significant correlation between the elementary school fourth grade students' reading motivation and their level of reading comprehension determined with the close test created from the informative text $(\mathrm{r}=.371 ; \mathrm{p}<.01)$ and their level of reading comprehension determined with the close test created from the narrative text $(\mathrm{r}=.364 ; \mathrm{p}<.01)$. The findings obtained through the correlation analysis conducted to determine the correlation between the students' reading comprehension scores determined with the open-ended questions and reading motivation are presented in Table 14.

Table 15. Comparison of the level of reading comprehension determined through the open-ended questions with their reading motivation

\begin{tabular}{lccc}
\hline \multicolumn{1}{c}{ Open-ended questions } & $\begin{array}{c}\text { Informative text } \\
\text { (Eating) }\end{array}$ & $\begin{array}{c}\text { Narrative text } \\
\text { (Arda is on Holiday) }\end{array}$ & $\begin{array}{c}\text { Reading } \\
\text { motivation }\end{array}$ \\
\hline $\begin{array}{l}\text { Informative text } \\
\text { (Eating) }\end{array}$ & 1 & & \\
$\begin{array}{l}\text { Narrative text } \\
\text { (Arda is on Holiday) }\end{array}$ & $.642^{* *}$ & 1 & \\
Reading motivation & $.359 * *$ & $.297 * *$ & 1 \\
\hline
\end{tabular}

$* * \mathrm{p}<.01$

As can be seen in Table 14, there is a positive, medium and significant correlation between the elementary school fourth grade students' reading motivation and their level of reading comprehension determined with the open-ended questions created from the informative text $(\mathrm{r}=.359 ; \mathrm{p}<.01)$ and their level of reading comprehension determined with the open-ended questions created from the narrative text $(\mathrm{r}=.297 ; \mathrm{p}<.01)$. When the extent to which reading motivation predicts reading comprehension was examined with the regression analysis, it was found that there is a positive and significant correlation between reading motivation and the reading comprehension levels determined with the eating 1 $(\mathrm{R}=.35 ; \mathrm{R} 2=12 ; \mathrm{p}<.01)$; the eating $2(\mathrm{R}=.37 ; \mathrm{R} 2=13 ; \mathrm{p}<.01)$; the Arda $1(\mathrm{R}=.29 ; \mathrm{R} 2=.08 ; \mathrm{p}<.01)$ and the Arda $2(\mathrm{R}=.36$; $\mathrm{R} 2=13 ; \mathrm{p}<.01)$ tests. Thus, it can be argued that the increase in the students' reading motivation positively and significantly affects reading comprehension. The results of the analyses have revealed that reading motivation can explain $12-13 \%$ of reading comprehension.

\section{Results and Discussion}

In the current study, the elementary school fourth grade students' reading motivation and reading comprehension scores determined with the close tests and open-ended questions were examined in relation to different variables. The results obtained from the analyses and evaluations are discussed in this section.

A total of 119 elementary school fourth grade students participated in the study. Of these students, 62 are females and 57 are males. The female students got higher scores from the close tests created with both the informative text and narrative text than the male students. On the basis of the gender variable, the level of reading comprehension was found to be significantly different in favor of the female students. As a result of the study conducted by Biyık, Erdoğan and Yildiz (2017) on 769 elementary school students, it was found that the value attached to reading by the students varies significantly depending on gender. The value attached to reading by the female students and their attitudes towards it are more positive than the male students. The students' reader self-concept and reading motivation vary significantly depending on gender. These results concur with the findings reported by Karaarslan (2015). In these three studies, the female students' reading comprehension levels are higher than those of the male students. Close tests developed to determine the reading comprehension level have been used in different studies. In the study carried out by Kizilaslan Tunçer and Erden (2015) on 40 elementary school fourth grade students, it was attempted to explore the role of close tests in determining the reading comprehension level. As a result, a medium correlation was found between close tests and reading comprehension tests. In a similar manner, Kurnaz (2018) conducted a study on the middle school seventh grade students in the city of Malatya and concluded that reading motivation directly affects reading comprehension in informative texts. "High rate of meaningless words used to fill in blanks or of blanks left uncompleted indicates that students haven't used linguistic clues that can be derived from sentences to find the correct words for blanks and have experienced problems in guessing meaning from texts" (Ulusoy, 2009, p.105).

In the current study, two different reading comprehension tests were used to determine the level of reading comprehension. One of them is the test made up of open-ended questions developed for the texts. The female students in the sampling took higher scores from this test when compared to the male students. The female students' reading comprehension scores are significantly higher than those of the male students. In a study conducted by Sert (2010) on the sixth grade students, it was found that there is a significant correlation between their reading comprehension and gender. Çetin (2017) conducted a study on 387 elementary school fourth grade students in Muğla and found that the female students' reading comprehension scores are higher than those of the male students. Kaya and Y1ldırım (2018) 
compared fluent reading and reading comprehension on the basis of gender and found that they do not vary significantly depending on gender. These differences between the research findings may have resulted from the differences of samplings and data collection tools. It has been reported that biological formation of girls and boys is an important factor to determine who they are and that more attention should be paid to the way in which societal gender and cultural elements are constructed (Watson, Kehler, Martino, 2010, p.358).

In the current study, it was also investigated whether the elementary school fourth grade students' reading comprehension levels vary significantly depending on whether they have taken pre-school education or not. The reading comprehension scores taken by the students having taken pre-school education from both the close tests and open-ended questions are higher. In a study conducted by Güleçol (2017), it was found that there is a significant correlation between the elementary school fourth grade students' reading comprehension levels and the variables of gender and having taken pre-school education or not. In a study by Büyükkaradağ (2017), it was found that the pre-school education of the elementary school first grade students experiencing difficulties in reading is shorter than that of the other students. The findings of the study conducted by Köseoğlu (2011) with the participation of 1162 seventh grade students in Elazığ have shown that the reading comprehension level of the students having taken pre-school education is higher than that of the students not having taken pre-school education. Different studies have also reported similar findings, which shows that pre-school education is an influential element for the development of elementary and secondary school students' reading skills.

Another variable investigated in the current study was the gender of the classroom teacher. The elementary school fourth grade students' level of reading comprehension was investigated in relation to the gender of their classroom teacher. The students' level of reading comprehension varies significantly depending on the gender of their classroom teacher. The reading comprehension level of the students whose classroom teacher is male is higher than that of the students whose classroom teacher is female. Şapcı and Kuşdemir (2018) also found that the informative text comprehension level of the elementary school fourth grade students whose classroom teacher is male is higher than that of the students whose classroom teacher is female. The quality of the written summaries is an important clue for the determination of the level of reading comprehension. Kuşdemir, Düşünsel and Çelik (2018) found that the elementary school fourth grade students' summary writing scores vary significantly depending on the gender of the classroom teacher. The students whose classroom teacher is male were found to be more successful in writing summary. When the findings of these studies are evaluated together, it can be argued that the gender of the classroom teacher is an important element influential on reading comprehension. Yet, it is difficult to reach a conclusive conclusion in this regard. Thus, it is believed that in order to conduct a more comprehensive discussion of the effect of the gender of the classroom teacher on reading comprehension and other language skills, new longitudinal studies using observations and interviews with different student groups and measurement tools are needed.

The current study also explored the reading motivation of the participating students. The reading motivation of the female students was found be higher than that of the male students. The increase in the students' reading motivation positively and significantly affects their level of reading comprehension. The study conducted by O'Garro (2017) on elementary school fourth and fifth grade students in the city of Midwest in America concluded that the reading motivation of the girls is higher than that of the boys. In schools, first students' reading anxiety should be decreased to enhance their reading motivation. Emphasis should be put on learning rather than tests and exams. Ways should be sought to arouse students' curiosity and students should be encouraged to make guesses about the subjects they have learned. Students informed about learning objectives should know what and why they will learn (Graves, et al, 2011, p.74). As a result of the study, it was determined that there is a positive and significant relationship between reading motivation and reading comprehension levels. In a study performed by Ylldiz (2013) with the fifth grade students, it was found that reading motivation positively affects reading comprehension at the level of $61 \%$. In research conducted on students of third grade or of higher grades, while continuous positive correlations were found between the intrinsic reading motivation and reading comprehension, negative or no correlations were found between the extrinsic reading motivation and reading comprehension (Taboada, Tonks, Wigfield \& Guthrie, 2009; Becker, McElvany and Kortenbruck, 2010; Andreassen and Bråten, 2010; Retelsdorf, Köller and Möller, 2011). In addition, for the third grade students, McElvany et al. (2008) reported that the correlation between reading motivation and reading comprehension is significant. According to a study carried out by Okur (2017) on elementary school fourth grade students, intrinsic motivation of the students having had pre-school education is higher than that of the students not having had pre-school education. Young children enjoying reading perform more frequent reading and they are more competent in reading; however, poor readers have low reading motivation. The first implication of this is that reading skill and motivation are mutually affecting each other. A total of 15 studies focusing on the relationship between young children's reading and self-efficacy beliefs and goal-orientedness have also been reviewed. The obtained results show that reading skills and motivation are partially correlated and they confirm the existence of a reciprocal relationship between them. 
Researchers, practitioners and parents should target both reading skills and motivation to help poor readers to be more competent readers (Morgan, 2007). Reading motivation of the students whose reading skills are developing has also been found to be increasing. When motivation increases, students participate more in reading activities, leading to increasing academic achievement (Guthrie, Wigfield, Metsala, \& Cox, 1999). Research findings show that it is important to evaluate and promote students' reading motivation starting from early ages so that their reading-comprehension development can be positively supported in elementary school years (Wigfield, Mason-Singh, Ho and Guthrie, 2014). In light of the results of the current study, following suggestions can be made:

1. The current study was conducted only on elementary school fourth grade students. Future research can investigate the reading comprehension of students from different grades of elementary school.

2. The current study was conducted with the participation of students only from Yerköy province of the city of Yozgat in Turkey. This can be seen as a limitation of the study. Future research can explore reading comprehension of students from different cities at national level.

3. The current study used close tests and open-ended questions to determine the students' level of reading comprehension. For the determination of the reading comprehension, retelling can also be used as well as rubrics and multiple-choice questions. For the diversity and effective use of such tests, teachers should also be willing and they should know the ways of assessment.

4. The positive correlation found between reading comprehension and reading motivation should be considered by teachers, reading experts, researchers and families. Particularly for the development of the reading skills of younger children, they should be encouraged to read, they should be helped to choose the books that want, they should be supported with individual support in challenging situations and rich reading environment should be established for them.

5. The fact that reading comprehension of female students is different from that of male students should not be overlooked. In order to more clearly understand the sociological and psychological components of this, new mixed longitudinal research focusing on only female students or male students can be designed.

As in many studies, the current study has some limitations. First, as the responses of 46 students in the sampling (Sampling: 165; $\mathrm{n}=119$ ) were excluded from the analyses as they did not correctly complete the data collection tool. This led to a loss of data that could not be prevented by the researcher. Second limitation is that the obtained results can only be generalized to the province of Yerköy. Another limitation is that the inferences and interpretations made on the conclusions reached on the basis of the collected data are the products of the researcher's own perspective. The analyses conducted in much of the research investigating reading and comprehension have revealed that the gender variable leads to a significant difference; yet, the biological and psychological causes of this have not been explored in detail. The current study has the same gender-related limitation. Moreover, the participants provided their answers in relation to motivation within the framework of the limited number of items presented to them. Different research methods can be used to determine particularly the intrinsic motivation.

\section{References}

Alkan, M. (2013). Comparison of different designs in scoring of PISA 2009 reading open ended items according to generalizability theory (Unpublished doctoral dissertation) Hacettepe University, Graduate School of Social Sciences, Ankara.

Andreassen, R., \& Braten, I. (2010). Examining the prediction of reading comprehension on different multiple choice tests. Journal of Research in Reading, 33(3), 263-283. https://doi.org/10.1111/j.1467-9817.2009.01413.x

Becker, M., McElvany, N., \& Kortenbruck, M. (2010). Intrinsic and extrinsic reading motivation as predictors of reading literacy: A longitudinal study. Journal Of Educational Psychology, 102(4), 773. https://doi.org/10.1037/a0020084

Bıyık, M. A., Erdoğan, T., \& Yıldız, M. (2017). The examining reading motivation of primary students in the terms of some variables. International Journal of Progressive Education, 13(3), 31-49. Retrieved May 15, 2018, from https://files.eric.ed.gov/fulltext/EJ1159916.pdf

Büyükkaradağ, B. (2017). The role of cognitive and psychosocial factors in development of reading and reading comprehension skills.(Unpublished master's thesis). Işsk University Graduate School of Social Sciences, İstanbul, Turkey.

Cohen, L., Manion, L., \& Morrison, K. (2007). Research methods in education, (6nd ed.) New York: Routledge, Taylor \& Francis. https://doi.org/10.4324/9780203029053 
Çetin, E. (2017). Effects of feelings in texts on reading comprehension skills of primary fourth graders. (Unpublished master's thesis). Muğla Sttkı Koçman University Graduate School of Education, Muğla, Turkey.

Çıkrıkçı, D. N. (2010). Açık uçlu soru formatı ve öğrenci izleme sistemi (ÖİS) akademik gelişimi izleme ve değerlendirme (AGID) modülündeki kullanımı. CİTO Eğitim: Kuram ve Uygulama, 21-30.

Çiftçi, Ö., \& Temizyürek, F. (2008). Measurement understanding of reading skills in 5 th classes of primary schools. Mustafa Kemal Journal of University Social Sciences Institute, 5(9), 109-129. http://dergipark.gov.tr/download/article-file/183190

Graves, M. F., Juel, C., Graves, B. B., \& Dewitz, P. (2011). Teaching reading in the 21st century (5. Bask1) Boston: Pearson Education.

Guthrie, J. T., Wigfield, A., Metsala, J. L., \& Cox, K. E. (1999). Motivational and cognitive predictors of text comprehension and reading amount. Scientific Studies Of Reading, 5(3), 231-256. https://doi.org/10.1207/s1532799xssr0303_3

Güleçol, S. (2017). Research on reading comprehension level of the 4th grade primary school students in various variabilities (Muğla Case).(Unpublished master's thesis).Muğla Sttkı Koçman University Graduate School of Education, Muğla, Turkey.

Harris, A. J., \& Sipay, E. R. (1990). How to increase reading abilitiy.(9nd ed.). New York: Longman

Karaarslan, Y. (2015). Reading and reading comprehension skill levels of primary students and the opinions that they are reading and reading comprehension difficulties faced by classroom teachers. (Unpublished master's thesis). Karadeniz Technical University Graduate School of Education Sciences, Trabzon, Turkey.

Karasu, H. P., Girgin, Ü., \& Uzuner, Y. (2013b). Evaluation of cloze procedure skills of hearing-impaired and normally-hearing students. Elementary Education Online (EEO), 12(3), 701-712.

Karasu, H. P.,Girgin, Ü., \& Uzuner, Y. (2013a). Formel Olmayan Okuma Envanteri. Ankara:Nobel Akademi Yayıncilik.

Kaya, D., \& Yıldırım, K. (2018). How does gender impact the relationship between reading fluency and reading comprehension? Journal of Human Sciences, 15(2), 931-942. https://doi.org/10.14687/jhs.v15i2.4784

Köseoğlu, E. (2011). Analysis of the primary school 7th grade students' levels of reading compherension in terms of various variables.(Unpublished master's thesis). Frrat University Institute of Educational Sciences, Elazığ, Turkey.

Kurnaz, H. (2018). Factors that affect reading comprehension in expository texts. (Unpublished doctoral dissertation). İnönü University Graduate School of Education Sciences, Malatya, Turkey.

Kuşdemir, Y., Düşünsel, C. M., \& Çelik, M. (2018). Investigation of summarization skills of primary school students. Journal of Human Sciences, 15(2), 893-910. Retrieved July 11, 2018. https://doi.org/10.14687/jhs.v15i2.5208

McElvany, N., Kortenbruck, M., \& Becker, M. (2008). Lesekompetenz und lesemotivation: entwicklung und mediation des zusammenhangs durch.Leseverhalten. Zeitschrift für Pädagogische Psychologie, 22(34), 207-219. https://doi.org/10.1024/1010-0652.22.34.207

Morgan, P. L., \& Fuchs, D. (2007). Is there a bidirectional relationship between children's reading skills and reading motivation? Exceptional Children, 73(2), 165-183. https://doi.org/10.1177/001440290707300203

O'Garro, J. A. (2017). Factors that influence the reading motivation of fourth and fifth grade students in a midwest urban elementary school.(Unpublished doctoral dissertation).The Graduate College at the University of Nebraska, USA.

Okur, B. (2017). The anaysis of 4th grade students' reading motivation and reader self perceptions in terms of various variables.(Unpublished master's thesis).Marmara University Graduate School of Education, Muğla, Turkey.

Putra, H. E. (2016). Improving the students' reading skill through cloze procedure technique Ta'dib, 13(1), 37-45. Retrieved May 15, 2018, from http://ecampus.iainbatusangkar.ac.id/ojs/index.php/takdib/article

Retelsdorf, J., Köller, O., \& Möller, J. (2011). On the effects of motivation on reading performance growth in secondary school. Learning and Instruction, 21(4), 550-559. https://doi.org/10.1016/j.learninstruc.2010.11.001

Ryan, R. M., \& Deci, E. L. (2000). Intrinsic and extrinsic motivations: Classic definitions and new directions Contemporary Educational Psychology 25, 54-67. https://doi.org/10.1006/ceps.1999.1020 
Schiefele, U., Stutz, F., \& Schaffner, E. (2016). Longitudinal relations between reading motivation and reading comprehension in the early elementary grades. Learning and Individual Differences, 51, 49-58. https://doi.org/10.1016/j.lindif.2016.08.031

Schirmer, B. (2010). Teaching the struggling reader. Boston: Pearson Education

Schunk,D. H. (2014) Learning Theories, (Trans. M. Şahin). Ankara: Nobel Yayın Dağıtım.

Sert, A. (2010). Investigation of sixth grade elementary students reading comprehension skills the evaluation of some variables (Unpublished master's thesis).Selçuk University Graduate School of Education Sciences, Konya, Turkey.

Slavin, R. E. (2013). Education psychology. (10nd ed.) (Trans. Ed. G. Yüksel). Ankara: Nobel Yayın Dağıtım.

Susanti, I., Buan, S., \& Suhartono, L. (2013).The use of cloze procedure to test the students reading comprehension. Jurnal Pendidikan dan Pembelajaran, 2(2).

Şapc1, D., \& Kuşdemir, Y. (2018). An investigation of the relationship between the ability In comprehension of expository texts and the ability in summarization of the primary school students. The Journal of Turk \& Islam World Social Studies, 5(17), 235-253. Retrieved July 20, 20180, from http://www.tidsad.com/Makaleler/1516548076_1527

Taboada, A., Tonks, S. M., Wigfield, A., \& Guthrie, J. T. (2009). Effects of motivational and cognitive variables on reading comprehension. Reading and Writing, 22(1), 85. https://doi.org/10.1007/s11145-008-9133-y

Tompkins, G. E. (2006). Literacy for the 21st centruy a balanced. (4nd ed.). New Jersey: Pearson

Tunçer, K. B., \& Erden, G. (2015). The utility of cloze tests for primary school 4th grade students' reading comprehension level. Bartin University Journal of Faculty of Education Special Issue on XIV. International Participation Symposium of Primary School Teacher Education, (21-23 May, 2015), 318-324. https://doi.org/10.14686/BUEFAD.2015USOSOzelsayi13219

Ulusoy, M. (2009). Boşluk tamamlama testinin okuma düzeyini ve okunabilirliği ölçmede kullanılması. Journal of Turkish Educational Sciences, 7(1), 105-126.

Üstüner, A., \& Şengül, M. (2004). Çoktan seçmeli test tekniğinin Türkçe öğretimine olumsuz etkileri. Firat Üniversitesi Sosyal Bilimler Dergisi, 14(2), 197-208.

Wang, J. H., \& Guthrie, J. T. (2004). Modeling the effects of intrinsic motivation, extrinsic motivation, amount of reading, and past reading achievement on text comprehension between U.S. and Chinese students. Reading Research Quarterly, 39, 162-186. https://doi.org/10.1598/RRQ.39.2.2

Watson, A., Kehler, M., \& Martino, W. (2010). The problem of boys' literacy underachievement: Raising some questions. Journal of Adolescent \& Adult Literacy, 53(5), 356-361. https://doi.org/10.1598/JAAL.53.5.1

Wigfield, A., Mason-Singh, A., Ho, A. N., \& Guthrie, J. T. (2014). Intervening to improve children's reading motivation and comprehension: Concept-oriented reading instruction. In Motivational Interventions (37-70). Emerald Group Publishing Limited. https://doi.org/10.1108/S0749-742320140000018001

Yildiz, M. (2013). The role of the reading motivation, reading fluency and reading comprehension on Turkish 5th graders' academic achievement. Turkish Studies, 8(4), 1461-1478.

http://www.acarindex.com/dosyalar/makale/acarindex-1423933003.pdf

\section{Copyrights}

Copyright for this article is retained by the author(s), with first publication rights granted to the journal.

This is an open-access article distributed under the terms and conditions of the Creative Commons Attribution license which permits unrestricted use, distribution, and reproduction in any medium, provided the original work is properly cited. 